\title{
Jurnalisme Damai Pemberitaan Tragedi Bom Surabaya Mei 2018 (Analisis Wacana Media Siber Kompas.com, Okezone.com, Liputan6.com)
}

\author{
Sherin Vania Angjaya, Eko Harry Susanto, Kurniawan Hari Siswoko \\ Sherinangjaya12@gmail.com
}

Fakultas Ilmu Komunikasi Universitas Tarumanagara

\begin{abstract}
Diversity is very closed by the Indonesian that consisted of various culture, background, ethnic, and religion which called by multicultural, it makes people learn to live dissimilarity with peace, but it keeps potentially raise conflict even the discrimination. This situation could be worse by the technology and information improvement specially in news online media that inform about the diversity tragedy. To fulfill people needs, news online media principally gives the important information that should be known by the people independently and factual, but the news also is made by people who called by the journalist whom have their own perspective and interpretation and also affected by their background and even the media prominence that should be not be implemented, it could make independent and objectivity the media changes. In this study, the case discuss about the application of peace journalism in online media Kompas.com, Liputan6.com, and Okezone.com about tragedy Bom Surabaya May 2018. This study uses kualitatif method discourse analys, also to brace up data validity that is being observed, directional interview, and found that three news online media are factual and carefully to inform about the diversity like peace journalism implemented of it.
\end{abstract}

Keywords: Peaceful Journalism, Principles of Journalism, Cyber Media

\begin{abstract}
Abstrak
Keberagaman sangat erat dengan masyarakat Indonesia yang terdiri dari berbagai budaya, latar belakang, etnis, dan agama yang disebut dengan multicultural. Hal tersebut membuat masyarakat belajar untuk hidup harmonis dengan sesama, namun adanya perbedaan tetap berpotensi memicu konflik bahkan perpecahan. Ditambah dengan kemajuan teknologi dan informasi yang terjadi terutama pada media komunikasi dan informasi media siber berita dalam memberitakan suatu peristiwa berkaitan dengan keberagaman. Media siber berita pada prinsipnya memberikan informasi yang penting diketahui kepada masyarakat berdasarkan fakta dan independen untuk memenuhi kebutuhan masyarakat. Namun pemberitaan media siber juga dibuat oleh jurnalis yang memiliki perspektif dan interpretasinya sendiri serta dipengaruhi juga oleh latar belakangnya dan bahkan adanya kepentingan media itu sendiri yang seharusnya tidak boleh diterapkan sehingga objektifitas dan independen media mulai bergeser. Dalam penelitian ini, peneliti membahas penerapan jurnalisme damai pada media siber Kompas.com, Liputan6.com, Okezone.com mengenai pemberitaan tragedi Bom Surabaya Mei 2018. Penelitian ini menggunakan metode kualitatif dengan analisis wacana, serta untuk menguatkan validitas data yang telah diamati, peneliti juga melakukan wawancara terarah, peneliti menemukan bahwa pemberitaan tiga media siber tersebut bersifat faktual dan hati-hati terutama pada berita terkait isu keberagaman seperti penerapan jurnalisme damai pada media siber tersebut.
\end{abstract}

Kata kunci: Jurnalisme Damai, Prinsip Jurnalisme, Media Siber 


\section{Pendahuluan}

Kemajuan teknologi berkembang pesat setiap waktunya sehingga mempengaruhi berbagai aspek kehidupan manusia termasuk media. Penyebaran informasi dan komunikasi pada masyarakat semakin mudah dengan munculnya media baru. Media baru dianggap lebih efektif dan efisien dibandingkan media lama seperti media cetak dan elektronik. Media baru tersebut adalah media siber yang dapat dijangkau oleh masyarakat kapan saja, dimana saja, dan oleh siapa saja. Keberadaan media siber juga memperluas peran jurnalistik dalam memberitakan informasi kepada masyarakat.

Jurnalis memiliki peran sangat penting dalam memberitakan sesuatu kepada masyarakat terutama di Indonesia yang memiliki masyarakat multikultural. Masyarakat Indonesia terdiri dari beragam latar belakang, budaya, agama, ras, dan etnis sehingga sering bermunculan perbedaan. Peran jurnalis dituntut untuk independen terutama dalam memberitakan suatu tragedi atau isu yang berkaitan dengan keberagaman.

Memasuki tahun 2016-an, isu keberagaman di Indonesia mulai memanas, yaitu sejak terjadinya kekuasaan yang dipegang oleh Gubernur DKI Jakarta Basuki Tjahja Purnama (Ahok) mengalami berbagai polemik politik yang akhirnya mengarah ke isu SARA. Polemik yang dirasakan Ahok saat itu cukup lama menjadi sorotan media hingga menimbulkan berbagai reaksi hingga aksi oleh masyarakat.

Selaras dengan sorotan media mengenai peristiwa tersebut, tahun 2018 Indonesia kembali merasakan hangatnya isu SARA yang menyelimuti multikultural masyarakat. Tepatnya bulan Mei 2018, terjadi tragedi tidak manusiawi bom bunuh diri di tempat ibadah yaitu Gereja daerah Surabaya, Jawa Timur.

Tragedi yang meresahkan tersebut menimbulkan berbagai kecaman dari berbagai pihak. Berdasarkan informasi resmi yang beredar bahwa pelaku bom bunuh diri tersebut disinyalir merupakan umat dari agama tertentu yang walaupun berakhir dengan penengasan tidak adanya agama yang dianut oleh pelaku tersebut.

Media yang menjadi alat pemenuh kebutuhan informasi dan komunikasi masyarakat, sangat berpengaruh pada perspektif dan nilai ideologi masyarakat. Isi berita yang berkaitan dengan isu keberagaman akan lebih mudah menarik perhatian masyarakat yang akhirnya akan menimbulkan reaksi tertentu. Situasi masyarakat multikultural lebih sensitif terhadap isi-isi berita yang menyebutkan agama, ras, budaya, dan etnis tertentu.

Dilihat dari sudut pandang media, perannya dalam memberitakan suatu tragedi yang tidak manusiawi tersebut sesuai dengan prinsip dan porsinya. Jurnalis mengesampingkan latar belakang agama dan budayanya terhadap kejadian yang terjadi untuk kepentingan masyarakat luas. Jurnalis dan media seharusnya tetap independen, faktual, tidak melebih-lebihkan, dan tidak mengurang-ngurangkan.

Pentingnya peran jurnalis dan media dalam menyuarakan keberagaman dan perdamaian membuat lahirnya /Jutnalisme Damai. Jurnalisme Damai pertama kali dipopulerkan oleh Johan Galtung yang kemudian dikembangkan oleh Jake Lynch dan McGoldrick.

Jurnalisme damai difokuskan pada diri jurnalis dan medianya sendiri, bagaimana jurnalis/media melihat sebuah konflik, bagaimana jurnalis/media mencari data dan informasi lainnya yang akurat dan faktual, bagaimana jurnalis/media menggunakan beberapa kata yang tepat agar tidak memicu konflik. 
Penelitian mengenai pemberitaan di media siber di Indonesia dirasakan sangat penting untuk saat ini, sehubungan dengan menjamurnya jumlah media siber di Indonesia yang tidak seimbang dengan kualitas serta mutu muatan berita yang dipublikasikannya, serta rendahnya rasa selektif masyarakat melihat berita pada media siber. Pemberitaan terkait isu-isu keberagaman yang sensitif dapat menimbulkan konflik dan perpecahan di masyarakat multikultural sehingga pentingnya peran media siber yang bukan hanya memberitakan suatu tragedi namun juga diimbangi dengan prinsip jurnalisme damai.

Penelitian ini juga menjadi penting karena mengamati sebuah tragedi besar yang terjadi di Indonesia berkaitan dengan kondisi masyarakat yang multikultural, penelitian dilakukan di tahun yang sama dengan tragedi tersebut, serta selain datadata yang didapatkan peneliti, penelitian ini juga didukung dengan sumber-sumber kredibel yaitu narasumber-narasumber utama atau kunci yang membuat penelitian ini relevan dan valid.

\section{Metode Penelitian}

Penelitian ini menggunakan metodologi deskriptif, mendefinisikan metodologi penelitian kualitatif sebagai prosedur penelitian yang menghasilkan data deskriptif berupa kata-kata tertulis atau lisan dari orang-orang dan perilaku yang dapat diamati (Endraswara, 2006). Penelitian yang bertujuan untuk menjelaskan secara lengkap penerapan prinsip jurnalisme damai pada pemberitaan media siber Kompas.com, Okezone.com, dan Liputan6.com, bagaimana media siber memberitakan suatu tragedi berkaitan dengan isu keberagaman, serta bagaimana penerapan prinsip jurnalisme pada media siber di Indonesia.

Dalam penjelasannya, penelitian ini menggunakan analisis wacana menurut Norman Fairclough yang menekankan pada pemahaman teks secara utuh dan diletakkan pada konteks sosialkultural dan latar belakang pembuat teks (Badara, 2012). Penelitian menganalisa pemberitaan di media siber Kompas.com, Okezone.com, dan Liputan6.com mengenai tragedi Bom Surabaya Mei 2018 menjadi tiga bagian yaitu secara analisa teks, proses, dan sosial.

Adapun teknik pengumpulan data yang digunakan penelitian yaitu observasi, wawancara, dan studi pustaka. Observasi yang dilakukan penelitian adalah pengamatan langsung berita-berita pada portal media masing-masing yaitu Kompas.com, Okezone.com, dan Liputan6.com. Teknik pengumpulan data yang kedua adalah wawancara, penelitian ini melakukan wawancara dengan narasumber utama yaitu Redaktur Eksekutif Kompas.com dan Liputan6.com, Wakil Pemimpin Redaksi Okezone.com, serta Ketua Umum Dewan Pers dan Aliansi Jurnalis Independen sebagai peneliti ahli.

\section{Hasil Temuan dan Diskusi}

Pemberitaan Media Siber di Indonesia Menerapkan Prinsip Jurnalisme

Setelah melakukan observasi, penelitian menemukan tidak adanya berita yang provokatif dan memicu konflik. Kompas.com, Okezone.com, dan Liputan6.com cenderung menulis berita dengan hati-hati. Ketiga media siber tersebut sama-sama menghindari penulisan berita yang provokatif dan sensasional.

Fungsi media siber itu sendiri adalah melalui pemberitaan, kampanye publik, iklan layanan masyarakat, dan propaganda, media diharapkan mampu berperan 
dalam menjaga keseimbangan alam, lingkungan sosial, ekonomi, dan politik yang berkembang dalam satu kawasan. Hal tersebut mengarah pada fungsi utama media massa itu sendiri yaitu menyampaikan informasi kepada masyarakat dalam Susanto (2018).

Berdasarkan jumlah media siber yang sangat banyak di Indonesia, sedikit pemberitaan media siber yang mengandung unsur provokasi. Sekalipun ada, media tersebut adalah media kecil yang jangkauan pembacanya juga kecil.

Menurut Dewan Pers, jumlah media siber di Indonesia sebanyak 43.000 media pada tahun 2018 tetapi hanya ratusan yang terverifikasi. Berdasarkan penerapan prinsip jurnalisme dan kode etik jurnalistik, 70\% dari jumlah media siber yang sudah mematuhi kode etik jurnalistik, dan sisanya yaitu berjumlah 30\% masih melanggar kode etik jurnalistik dan tidak akurat. Temuan tersebut diperoleh berdasar kutipan anggota Dewan Pers, Nezar Patria.

Pelanggaran yang sering ditemukan pada media siber di Indonesia adalah informasi tidak terverifikasi, banyaknya media yang me-copy paste tulisan media lain tanpa pertanggung jawaban, dan lain-lain. Hal tersebut sesuai dengan kutipan narasumber utama penelitian, Ketua Umum Dewan Pers, Yoseph Adi, yang menyatakan bahwa banyaknya media yang abal-abal yang menjiplak berita dari media seperti Jawa Pos Grup, Kompas Grup, dan bagi media-media yang sudah terverifikasi tetapi masih ditemukan pelanggaran, sering ditemukan pelanggaran tidak melakukan konfirmasi dengan alasan terburu-buru.

Namun media siber di Indonesia yang melanggar kode etik jurnalistik dengan membuat berita yang provokatif ditemukan berskala kecil karena saat ini sedang diiringi dengan upaya Dewan Pers dalam melakukan fungsi pengawasan. Dewan Pers sedang melakukan uji sertifikasi dan uji kompetensi pers terhadap media-media siber. Dewan Pers juga telah menyediakan laman pada website resminya yang berisi daftar media yang sudah terverifikasi, sertifikasi, dan lulus uji kompetensi. Upaya tersebut juga dapat mempermudah masyarakat mengetahui media apa saja yang dapat dipercaya validitas beritanya.

Penerapan Jurnalisme Damai pada Media Siber Kompas.com, Okezone.com, Liputan6.com

Bagi jurnalis dan pengelola media massa, bahasa bukan sekedar alat komunikasi untuk menyampaikan informasi atau peristiwa. Bahasa juga bukan sekedar alat untuk menggambarkan realitas. Lewat pilihan diksi, media massa menentukan gambaran-gambaran atau citra tertentu yang hendak ditanamkan kepada benak publik atau pembaca (J. Anto, 2007).

Jurnalisme Damai di Indonesia memang masih belum diutamakan oleh mediamedia. Penerapannya seringkali digunakan disaat dibutuhkan saja atau menjadi pelaras akhir terbentuknya berita, terutama pada isi berita terkait isu keberagaman atau konflik tertentu, barulah media menyeimbangkan isi beritanya dengan Jurnalisme Damai. Hal ini berdasar atas kutipan narasumber utama penelitian yaitu Ketua Umum AJI, Abdul Manan.

Penerapan Jurnalisme Damai dalam pemberitaan Tragedi Bom Surabaya Mei 2018 pada media siber Kompas.com, Okezone.com, Liputan6.com dapat ditemukan. Setelah melakukan observasi berita di masing-masing portal media tersebut, temuannya adalah berita-berita mengenai tragedi tersebut banyak ditulis dengan menggunakan kata-kata yang halus dan tidak provokatif. Penulisan berita juga tidak 
menyebutkan tersangka atau pelaku bom yang mengaitkan dengan agama tertentu, hal tersebut menunjukkan penerapan jurnalisme damai yang semestinya.

Berita-berita yang ditemukan dari ketiga media tersebut juga memiliki kesamaan yaitu menulis berita dengan hati-hati dan mengutip pembicaraan tokohtokoh penting yang sekiranya dapat mempengaruhi masyarakat. Berita diisi dengan kalimat persuasif atau ajakan dengan mengutip narasumber seorang tokoh seperti Presiden Joko Widodo, tokoh agama Romo dan Rektor Al-Azhar, serta pihak keamanan kepolisian.

Berdasarkan hasil analisis yang dilakukan penelitian, berita-berita yang ditemukan dari masing-masing media siber tersebut dilakukan analisa wacana dengan menggunakan metode analisis wacana menurut Norman Fairclough. Analisa wacana tersebut membagi menjadi 3 bagian analisis, yaitu analisa teks, proses, dan sosial (Fairclough, 2003).

Hasil ananalisa wacana yang dilakukan peneliti memiliki kesamaan diantara berita-berita yang ditemukan dari ketiga media siber tersebut.

1) Analisis Teks

Temuan peneliti mencakup 3 berita dari masing-masing media yang menunjukkan penerapan jurnalisme damai dalam pemberitaannya. Pada media Kompas.com, ditemukan 3 berita yang ketiganya sama-sama menggunakan kutipan para tokoh penting negara dengan mengajak masyarakat untuk bersikap tenang dan tidak terprovokasi. Temuan tersebut menunjukkan berita yang ditulis Kompas.com tersebut bersifat persuasif dan hati-hati karena pemberitaannya tidak semata-mata dibuat oleh jurnalisnya namun hasil kutipan tokoh penting negara.

Hasil analisa tersebut juga ditemukan pada pemberitaan media Okezone.com. 3 berita yang ditemukan peneliti pada portal media Okezone.com, menunjukkan bahwa ketiga berita tersebut juga bersifat persuasif dengan mengutip pembicaraan tokoh penting negeri.

Liputan6.com juga melakukan hal yang sama dalam pemberitaan tragedi Bom Surabaya Mei 2018. Menghindari kata-kata yang provokatif serta menyebutkan agama tertentu didalamnya menunjukkan bahwa Liputan6.com menulis berita dengan hati-hati. Hasil analisa penelitiann juga menunjukkan hal yang sama seperti Kompas.com dan Okezone.com, bahwa pemberitaannya berisi dengan kutipan tokoh penting negeri yang bersifat persuasif kepada pembacanya.

2) Analisis Proses

Hasil analisa penelitian menunjukkan adanya kesamaan pada ketiga media Kompas.com, Okezone.com, dan Liputan6.com dalam pemberitaannya. Analisa proses yang dilakukan adalah melihat unsur-unsur lain yang mempengaruhi pembuatan berita. Termasuk waktu pembuatan dan publikasian berita. Ketiga media tersebut sama-sama mempublikasikan berita tepat di hari kejadian sampai 2 hari setelahnya. Hal tersebut menunjukkan proses pemberitaannya situasional dengan waktu yang tepat dan isi berita bersifat persuasif disaat masyarakat sedang resah atas kejadian teror bom tersebut.

3) Analisis Sosial

Kompas.com, Okezone.com, dan Liputan6.com memiliki masing-masing visi, misi, ideologi, dan prinsip media yang dianutnya. Penelitian dengan 
melakukan analisis sosial ini menganalisa isi berita media dengan prinsip media yang dianutnya. Hasil analisa sosial yang telah dilakukan ini menunjukkan bahwa adanya kesesuaian antara isi berita yang dibuatnya dengan ideologi media yang dianutnya.

Prinsip jurnalisme damai yang bertujuan untuk menciptakan perdamaian pada masyarakat yang dituangkan pada pengemasan berita, diterapkan oleh ketiga media siber tersebut dengan mengajak masyarakat untuk tetap berpersepsi positif terhadap tragedi yang terjadi dengan terus menekankan ideologi-ideologi yang dianut di Indonesia serta nilai-nilai agama. Makna berita juga disampaikan dengan penggunaan kutipan pembicara tokoh-tokoh penting yang dapat mempengaruhi persepsi masyarakat atau pembacanya.

Hasil analisa wacana yang terdiri dari analisis teks, proses, dan sosial tersebut sesuai dengan prinsip jurnalisme damai yaitu "The media have the power to contribute to the information of attitudes and opinions and to increase knowledge and awareness by supplying information" (Bractic, 2006).

\section{Belum Sepenuhnya Media Siber Menerapkan Prinsip Jurnalisme}

Prinsip-prinsip jurnalisme yang dimaksud bukan hanya tulisan dalam pemberitaan, tetapi juga keseluruhan pemberitaan seperti pembuatan judul, penyajian foto dan vidio, dan lain-lain. Penyajian foto dan vidio juga hal yang paling sering masih dilanggar oleh media siber. Peneliti tidak menemukan artikel berita yang melanggar penyajian foto dan vidio yang tidak semestinya karena media siber tersebut sudah ditegur oleh Dewan Pers dan langsung dibenahi isi konten pemberitaannya.

Temuan pada media siber Liputan6.com menemukan satu pelanggaran kode etik jurnalistik pada tragedi Bom Surabaya Mei 2018 dalam bentuk vidio dan diakui juga dengan pernyataan oleh Redaktur Eksekutif Liputan6.com, Irna, yang diwawancarai secara langsung.

Pernyataan tersebut menunjukkan bahwa adanya pelanggaran kode etik jurnalistik yang berbentuk vidio yang tidak selayaknya tayang di portal media, namun peneliti tidak menemukan artikel berita tersebut di portal media Liputan6.com karena artikel tersebut sudah dibenahi dan dikoreksi oleh pihak redaksi.

Hasil analisa tersebut menunjukkan bahwa belum semua media siber di Indonesia menerapkan prinsip jurnalisme sesuai yang berlaku, seperti pada pedoman media siber (Susanto, 2018) menyebutkan beberapa aspek terkait dengan Pedoman Pemberitaan Media Siber.

\section{Simpulan}

Pada penelitian Jurnalisme Damai dalam Pemberitaan Tragedi Bom Surabaya Mei 2018 (Analisis Wacana pada Media Siber Kompas.com, Liputan6, Okezone.com), peneliti dapat menyimpulkan bahwa: 1) Pemberitaan media siber di Indonesia yang menimbulkan konflik berkurang. Terutama pada media mainstream seperti Kompas.com, Okezone.com, dan Liputan6.com tidak ditemukannya berita yang provokatif dan menimbulkan konflik. Isi berita pada media siber di Indonesia secara umum yang bombastis, sensasional, dan provokatif masih ditemukan namun sedikit jumlahnya. Berita-berita yang provokatif banyak ditemui pada media siber yang tidak jelas, belum terverifikasi, dan sertifikasi; 2) Media siber Kompas.com, 
Okezone.com, dan Liputan6.com sudah menerapkan prinsip jurnalisme damai sebagaimana dalam pemberitaan Tragedi Bom Surabaya Mei 2018. Ketiga media siber tersebut sangat berhati-hati memberitakan suatu tragedi yang terjadi cukup besar dan menerapkan prinsip-prinsip jurnalisme dalam pengemasan beritanya. Enggan memburu clickbait serta mempertimbangkan masa depan reputasinya, ketiga media tersebut tetap berjalan pada ideologi media yang dianutnya dengan memberitakan sesuai fakta dan menciptakan nilai positif bagi pembacanya; dan 3) Penerapan prinsip-prinsip jurnalisme masih belum sepenuhnya diterapkan oleh media siber di Indonesia. Prinsip jurnalisme yang berlaku di Indonesia seperti kode etik jurnalistik, pedoman media siber Indonesia, dan UU No. 40 Tahun 1999 tentang Pers masih ditemukan pelanggaran yang dilakukan oleh media siber di Indonesia. Pelanggaran yang sering ditemukan antara lain menyebutkan identitas korban atau pelaku dibawah umur, data tidak terkonfirmasi, penyajian foto dan vidio yang vulgar atau menunjukkan identitas pelaku atau korban dibawah umur. Banyaknya pelanggaran tersebut dilakukan oleh media-media siber yang tidak jelas dan terverifikasi, media siber mainstream sudah cukup menerapkan prinsip jurnalisme yang berlaku.

\section{Ucapan Terima Kasih}

Penelitian Jurnalisme Damai dalam Pemberitaan Tragedi Bom Surabaya Mei 2018 (Analisis Wacana Media Siber Kompas.com, Okezone.com, Liputan6.com) dapat terlaksana karena dukungan dari berbagai pihak, yaitu Bp. Dr. Eko Harry Susanto, M.Si., dan Bp. Kurniawan Hari Siswoko, S.I.P., M.A, selaku dosen pembimbing dan co- pembimbing, Bp. Yoseph Adi, Bp. Abdul Manan, Bp. Fetra Hariandja, Bu Irna selaku narasumber utama penelitian yang terdiri dari Ketua Umum Dewan Pers, Ketua Umum AJI, Wakil Pemimpin Redaksi Okezone.com, dan Redaktur Eksekutif Liputan6.com, dan dosen-dosen peneliti yaitu Bp. Gafar Yoedtadi, Bp. Ahmad Junaidi, dan Bu Zita, serta pihak-pihak lainnya yang mendukung proses penelitian ini sejak awal dimulai hingga selesai.

\section{Daftar Pustaka}

Badara, Aris. (2012). Analisis Wacana: Teori, Metode, dan Penerapannya pada Wacana Media. Jakarta: Kencana

Endraswara, Suwardi. (2006). Metode, Teori, Teknik Penelitian Kebudayaan: Ideologi, Epistemologi, dan Aplikasi. Sleman: Pustaka Widyatma

Fairclough, Norman. (2003). Analysing Discourse: Textual for Social Research. New York: Routledge

J, Anto. (2007). Meretas Jurnalisme Damai di Aceh - Kisah Reintegerasi Damai dari Lapangan. Jakarta: Yayasan Obor Indonesia

Lynch, Jake, \& McGoldrick, Annabel. (2005). Peace Journalism. Los Angeles: Hawthorn Press

Susanto, E. Haryanto. (2017). Conflict Between Groups of Different Religion and Beliefs Posing of as Threats to Heterogenity in Indonesia. Modern Applied Science. Vol. 11, no. 12. 1913-1844

Susanto, E. Haryanto. (2018). Komunikasi Manusia: Teori dan Praktek dalam Penyampaian Gagasan. Yogyakarta: Mitra Wacana Media 